\title{
Investigation on the role of XPG gene polymorphisms in breast cancer risk in a Chinese population
}

\author{
S.H. Ma ${ }^{1,2}$, F.H. Ling' ${ }^{2}$ Y.X. Sun ${ }^{3}$, S.F. Chen ${ }^{2}$ and Z. Li ${ }^{1}$ \\ ${ }^{1}$ Department of General Surgery, Zhujiang Hospital, \\ Southern Medical University, Guangzhou, China \\ ${ }^{2}$ Department of Mammary Gland Surgery, Zhongshan Hospital, \\ Sun Yat-sen University, Zhongshan, China \\ ${ }^{3}$ Department of Cardiovascular Medicine, Zhongshan Hospital, \\ Sun Yat-sen University, Zhongshan, China \\ Corresponding author: Z. Li \\ E-mail: lizhoujj@163.com
}

Genet. Mol. Res. 15 (2): gmr. 15028066

Received November 17, 2015

Accepted January 18, 2016

Published June 3, 2016

DOI http://dx.doi.org/10.4238/gmr.15028066

\begin{abstract}
We conducted a case-control study to investigate the role of XPG gene polymorphisms (rs2094258, rs751402, and rs17655) in the development of breast cancer. Patients with breast cancer (320) and control subjects (294) were consecutively selected from the Zhongshan Hospital between April 2013 and January 2015. The genotyping of XPG rs2094258, rs751402, and rs17655 was performed using polymerase chain reaction-restriction fragment length polymorphism. Using the chisquare test, we did not find any significant differences in the genotype distributions of XPG rs2094258 $\left(\chi^{2}=1.48, \mathrm{P}=0.48\right)$, rs751402 $\left(\chi^{2}=\right.$ $0.65, \mathrm{P}=0.72)$, and rs17655 $\left(\chi^{2}=0.01, \mathrm{P}=0.92\right)$ genes between breast cancer patients and control subjects. The genotype distributions of XPG rs2094258, rs751402, and rs17655 did not deviate from the HardyWeinberg equilibrium in control subjects, and the $\mathrm{P}$ values were 0.58 , 0.97 , and 0.26 , respectively. Using unconditional logistic regression
\end{abstract}


analysis, we found that XPG rs2094258, rs751402 and rs17655 gene polymorphisms are not associated with the development of breast cancer after adjusting for potential confounding factors. In conclusion, we found that XPG rs2094258, rs751402, and rs17655 do not influence the development of breast cancer in a Chinese population.

Key words: XPG; Polymorphism; Breast cancer; Chinese population

\section{INTRODUCTION}

Breast cancer is the most common cancer and the third most common cause of cancerrelated death for women in China (Siegel et al., 2014). Furthermore, the number of women in China suffering from breast cancer shows a tendency to increase, while the number of death tends to decrease (Matsen and Neumayer, 2013). The development of breast cancer is a complex process and depends of multiple factors, including age, family history of breast cancer, lack of physical activity, menstrual and reproductive history, and dense breast tissue (Abu Rabi et al., 2015; Zhang et al., 2015). However, not all individuals will develop breast cancer, even when exposed to the same risk factors for this type of cancer, which suggests that genetic factors are contributing to the development of breast cancer.

In humans, there are more than 130 genes involving in the DNA repair pathways. There are five common DNA repair pathways, including base excision repair, nucleotide excision repair (NER), mismatch repair, and double-strand break repair pathways. NER pathway plays an important role in removing DNA lesions caused by UV radiation or chemical agents (Friedberg et al., 2000). The XPG belongs to NER, and this gene has a function of extreme UV-sensitivity and a high genetic predisposition to sunlight-caused cancers (Cordonnier and Fuchs, 1999). Previous studies have shown that XPG gene polymorphisms are associated with development of several kinds of cancers, such as digestive system cancer, head and neck cancer, colorectal cancer, prostate cancer, laryngeal cancer, and bladder cancer (Du et al., 2014; Liu et al., 2014; Lu et al., 2014; Mirecka et al., 2014; Jiang et al., 2015; Yu et al., 2015). In particular, there are a few studies reporting on the association between XPG gene polymorphisms and the development of breast cancer, but the results are inconclusive (Kumar et al., 2003; Mechanic et al., 2006; Crew et al., 2007; Ding et al., 2011). In our study, we conducted a case-control study to investigate the role of XPG gene polymorphisms (rs2094258, rs751402, and rs 17655) in the development of breast cancer.

\section{MATERIAL AND METHODS}

\section{Subjects}

This case-control study included 344 patients with breast cancer, and they were consecutively selected from the Zhongshan Hospital between April 2013 and January 2015. All the newly patients with breast cancer were independently confirmed by two pathologists through histopathological analysis. Patients who had secondary or recurrent tumors, a history of other malignant tumors, or serious infection diseases were excluded from this study. Finally, 320 patients with breast cancer were included in this study (participation rate was 90.02\%).

During the same period time, 294 females were consecutively randomly selected from 
individuals who had a health check-up at our hospital. Controls who had a history of malignant tumor, hyperplasia of mammary glands, and serious infection disease, kidney and liver diseases were included into our study. Each patient and control subject signed a written informed consent before participating in our study. The study protocol was approved by the Ethics Committee of the Zhongshan Hospital and was according to the standards of the Declaration of Helsinki.

The demographic and clinical data of patients with breast cancer and control subjects were collected from the medical records and from a structured questionnaire. The collected information included age, menopause, age at menarche, age at first live birth, family history of cancer, clinical stage, and tumor size.

\section{DNA extraction and genotyping}

A sample of peripheral blood $(5 \mathrm{~mL})$ was collected from each patient and control subject, and the DNA was extracted from the collected blood samples using the TIANamp Blood DNA Kit (Tiangen, Beijing, China) following the instructions. The genotyping of XPG rs2094258, rs 751402, and rs 17655 was performed by polymerase chain reaction-restriction fragment length polymorphism (PCR-RFLP). The primers of XPG rs2094258, rs751402, and rs 17655 were designed using the Primer premier v5.0 software (PREMIER Biosoft Ltd., Palo Alto, CA, USA). The PCR for analysis was performed in a reaction of $25 \mu \mathrm{L}$ solution of 10 pmol primers and $50 \mathrm{ng}$ genomic DNA. The PCR condition was started at a denaturation temperature of $94^{\circ} \mathrm{C}$ for $5 \mathrm{~min}$, followed by 30 cycles of denaturation at $94^{\circ} \mathrm{C}$ for $30 \mathrm{~s}$, annealing at $60^{\circ} \mathrm{C}$ for $60 \mathrm{~s}$, extension at $72^{\circ} \mathrm{C}$ for $60 \mathrm{~s}$, and a final extension for $7 \mathrm{~min}$ at $72^{\circ} \mathrm{C}$. Digestion products were determined by electrophoresis using ethidium bromide staining, a $2 \%$ agarose gel and observed by ultraviolet light.

\section{Statistical analysis}

The demographic and lifestyle information between breast cancer patients and control subjects was compared using the chi-square $\left(\chi^{2}\right)$ test. The genotype frequencies of XPG rs2094258, rs751402, and rs17655 confirmed with the Hardy-Weinberg equilibrium (HWE) were analyzed using the $\chi^{2}$ test with one degree of freedom. The association between XPG rs2094258, rs751402, and rs17655 gene polymorphisms and the development of breast cancer was analyzed using unconditional regression analysis, and the results were described using odds ratios and $95 \%$ confidence intervals. The wide-type genotype of XPG rs2094258, rs751402, and rs17655 was taken as the reference group. All the statistical analysis was performing using the SPSS 16.0 statistical software (SPSS, Chicago, IL, USA), and a P value $<0.05$ was considered as a significant difference.

\section{RESULTS}

The demographic and clinical characteristics of the breast cancer patients and control subjects are presented in Table 1. Compared to the control subjects, breast cancer patients were more likely to be in menopause $\left(\chi^{2}=11.65, \mathrm{P}<0.001\right)$, have no children $\left(\chi^{2}=21.33, \mathrm{P}<\right.$ $0.001)$, and have a family history of cancer $\left(\chi^{2}=5.33, \mathrm{P}=0.02\right)$. No significant difference was found between breast cancer patients and controls in terms of age $\left(\chi^{2}=0.17, \mathrm{P}=0.68\right)$ and age at menarche $\left(\chi^{2}=3.36, \mathrm{P}=0.06\right)$. 
Table 1. Demographic and clinical characteristics of breast cancer patients and controls in this study.

\begin{tabular}{|c|c|c|c|c|c|c|}
\hline Characteristics & Patients $(\mathrm{N}=320)$ & $\%$ & Controls $(\mathrm{N}=294)$ & $\%$ & $\chi^{2}$ test & $P$ value \\
\hline \multicolumn{7}{|l|}{ Age (years) } \\
\hline$<50$ & 146 & 45.63 & 139 & 47.28 & & \\
\hline$\geq 50$ & 174 & 54.38 & 155 & 52.72 & 0.17 & 0.68 \\
\hline \multicolumn{7}{|l|}{ Menopause } \\
\hline No & 241 & 75.31 & 184 & 62.59 & & \\
\hline Yes & 79 & 24.69 & 110 & 37.41 & 11.65 & $<0.001$ \\
\hline \multicolumn{7}{|c|}{ Age at menarche } \\
\hline$<15$ & 234 & 73.13 & 195 & 66.33 & & \\
\hline$\geq 15$ & 86 & 26.88 & 99 & 33.67 & 3.36 & 0.06 \\
\hline \multicolumn{7}{|c|}{ Age at first live birth } \\
\hline No children & 40 & 12.50 & 9 & 3.06 & & \\
\hline$<30$ & 98 & 30.63 & 119 & 40.48 & & \\
\hline$\geq 30$ & 182 & 56.88 & 165 & 56.12 & 21.33 & $<0.001$ \\
\hline \multicolumn{7}{|c|}{ Family history of cancer } \\
\hline No & 282 & 88.13 & 275 & 93.54 & & \\
\hline Yes & 38 & 11.88 & 19 & 6.46 & 5.33 & 0.02 \\
\hline \multicolumn{7}{|l|}{ Tumor size } \\
\hline$<2.0 \mathrm{~cm}$ & 268 & 83.75 & & & & \\
\hline$\geq 2.0 \mathrm{~cm}$ & 52 & 16.25 & & & & \\
\hline \multicolumn{7}{|l|}{ Clinical stage } \\
\hline I-II & 227 & 70.94 & & & & \\
\hline III-IV & 93 & 29.06 & & & & \\
\hline
\end{tabular}

Using the chi-square test, we did not find any significant difference in the genotype distributions of XPG rs2094258 $\left(\chi^{2}=1.48, \mathrm{P}=0.48\right), \mathrm{rs} 751402\left(\chi^{2}=0.65, \mathrm{P}=0.72\right)$, and rs $17655\left(\chi^{2}=0.01, \mathrm{P}=0.92\right)$ genes between breast cancer patients and control subjects (Table 2). The genotype distributions of XPG rs2094258, rs751402, and rs17655 did not deviate from the HWE in control subjects, and the P values were $0.58,0.97$, and 0.26 , respectively.

Table 2. Genotype frequencies of XPG rs2094258, rs 751402, and rs 17655 gene polymorphisms between breast
cancer patients and controls.
\begin{tabular}{l|c|c|c|c|c|c|c}
\hline XPG & Patients (N = 320) & $\%$ & Controls (N =294) & $\%$ & $\chi^{2}$ test & P value & P for HWE \\
\cline { 3 - 8 } & & & & & & In controls \\
\hline rs2094258 & & & & & & & \\
\hline AA & 157 & 49.06 & 127 & 56.16 & & & \\
\hline AG & 136 & 42.19 & 96 & 38.51 & & & \\
\hline GG & 27 & 8.44 & 15 & 5.33 & 1.48 & 0.48 & 0.58 \\
\hline rs751402 & & & & & & & \\
\hline CC & 127 & 39.69 & 101 & 47.04 & & & \\
\hline CT & 150 & 46.88 & 107 & 41.15 & & & \\
\hline TT & 43 & 13.44 & 28 & 11.81 & 0.65 & 0.72 & 0.97 \\
\hline rs17655 & 116 & 36.25 & 84 & 43.6 & & & \\
\hline GG & 145 & 45.31 & 107 & 40.75 & & & \\
\hline GC & 59 & 18.44 & 46 & 15.65 & 0.01 & 0.92 & 0.26 \\
\hline CC & & & & & & & \\
\hline
\end{tabular}

Using unconditional logistic regression analysis, we found that XPG rs2094258, rs751402, and rs17655 gene polymorphisms could not influence the development of breast cancer, after adjusting for potential confounding factors (Table 3). Moreover, we performed 
a gene-environmental interaction between XPG rs2094258, rs751402, and rs17655 gene polymorphisms and the demographic characteristics of breast cancer, but no significant interaction was found between them $(\mathrm{P}<0.05)$.

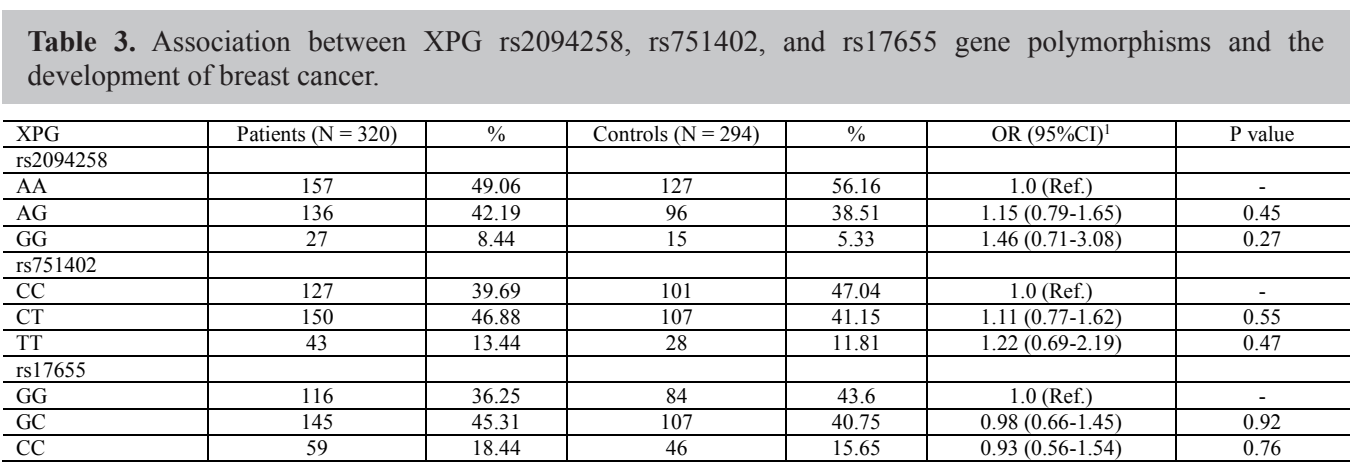

${ }^{1}$ Adjusted for age, menopause, age at first live birth, and family history of cancer.

\section{DISCUSSION}

Polymorphisms in the XPG gene can alter the expression of this protein and influence its function of correcting the excision repair deficiency, and thus cause a reduced DNA repair capacity and influence the cancer susceptibility (Mudgett and MacInnes, 1990; Takahashi et al., 1992). In the present study, we conducted a case-control study to investigate the association between three common SNPs (rs2094258, rs751402, and rs17655) in the XPG and the development of breast cancer in a Chinese population, and we found that the three SNPs do not contribute to the development of breast cancer.

Previous studies have reported that XPG gene polymorphisms are associated with several kinds of cancers in different ethnicities, such as head and neck cancer, gastric cancer, bladder cancer, colon cancer, prostate cancer (Ma et al., 2012; He et al., 2012; Zhu et al., 2012; Liu et al., 2014; Steck et al., 2014; Zhang et al., 2014). Ma et al. (2012) conducted a casecontrol study of 1059 patients with head and neck cancer and 1066 control subjects, and they reported that XPG gene polymorphisms may not affect the risk of head and neck cancer in an American population. He et al. (2012) conducted a case-control study in a Chinese population, and they reported that $\mathrm{rs} 2296147 \mathrm{~T}>\mathrm{C}$ and $\mathrm{rs} 2094258 \mathrm{C}>\mathrm{T}$ genetic variants may contribute to the risk of gastric cancer. Liu et al. (2014) conducted a meta-analysis with eight casecontrol studies and reported that the XPG rs17655 polymorphism was not associated with bladder cancer risk. Steck et al. (2014) did not find significant association between XPG gene polymorphisms and colon cancer risk. Zhang et al. (2014) reported that the XPG rs2296147 polymorphism was significantly correlated with prostate cancer susceptibility in a Chinese population. Zhu et al. (2012) suggested that XPG rs2296147 C variant genotypes were associated with a significantly lower ESCC risk in a Chinese population.

Several previous studies have reported the association between XPG gene polymorphisms and the development of breast cancer, but the results are inconclusive (Kumar et al., 2003; Mechanic et al., 2006; Crew et al., 2007; Ding et al., 2011; Xu et al., 2014). Kumar et al. (2003) conducted a case-control study with 220 breast cancer patients and 308 controls, 
and reported that the XPG gene marginally significantly increased the development of breast cancer in a Swedish population. Mechanic et al. (2006) conducted a study in an AfricanAmerican population, composed by 2311 cases and 2022 controls, and they did not observe a significant association between XPG gene polymorphisms and the development of breast cancer. Ding et al. (2011) suggested that the XPG rs17655 polymorphism is not associated with an increased breast cancer risk in a Chinese population. Xu et al. (2014) conducted a meta-analysis with 5235 breast cancer patients and 5685 control subjects, and they suggested that the XPG rs17655 polymorphism is not associated with breast cancer risk. In our study, no significant association was found between XPG rs2094258, rs751402, and rs17655 gene polymorphisms and breast cancer risk. The discrepancies of the above mentioned studies may be caused by different populations, selection of patients and controls, and sample sizes. Further studies are needed to confirm the findings of our study.

There are two limitations in our study. First, the selection bias could not be avoided, since the patients and controls were selected from one hospital. However, the genotype distributions of XPG rs2094258, rs751402, and rs17655 confirmed with the HWE in control subjects suggested that the study population could represent the general population. Second, the sample size is relatively small in our study, which may limit the statistical power to find differences between groups. The small sample size may explain no association between XPG rs2094258, rs751402, and rs 17655 gene polymorphisms and risk of breast cancer in this study.

In conclusion, we found that XPG rs2094258, rs751402, and rs17655 do not influence the development of breast cancer in a Chinese population, and further studies with a large sample size and more ethnicities are needed to confirm our results.

\section{Conflicts of interest}

The authors declare no conflict of interest.

\section{ACKNOWLEDGMENTS}

We thank the staff in Zhongshan Hospital, and who help us to collect the blood samples from study subjects.

\section{REFERENCES}

Abu Rabi Z, Zoranovic T, Milovanovic J, Todorovic-Rakovic N, et al. (2015). Breast cancer in postmenopausal patients: Impact of age. J. Balk. Union Oncol. 20: 723-729. Cordonnier AM, Fuchs RP (1999). Replication of damaged DNA: molecular defect in xeroderma pigmentosum variant cells. Mutat. Res. 435: 111-119.

Cordonnier AM and Fuchs RP (1999). Replication of damaged DNA: molecular defect in Xeroderma pigmentosum variant cells. Mut. Res. 435: 111-119.

Crew KD, Gammon MD, Terry MB, Zhang FF, et al. (2007). Polymorphisms in nucleotide excision repair genes, polycyclic aromatic hydrocarbon-DNA adducts, and breast cancer risk. Cancer Epidemiol. Biomarkers Prev. 16: 2033-2041. http://dx.doi.org/10.1158/1055-9965.EPI-07-0096

Ding DP, He XF and Zhang Y (2011). Lack of association between XPG Asp1104His and XPF Arg415Gln polymorphism and breast cancer risk: a meta-analysis of case-control studies. Breast Cancer Res. Treat. 129: 203-209. http://dx.doi. org/10.1007/s10549-011-1447-9

Du H, Zhang X, Du M, Guo N, et al. (2014). Association study between XPG Asp1104His polymorphism and colorectal cancer risk in a Chinese population. Sci. Rep. 4: 6700. http://dx.doi.org/10.1038/srep06700

Friedberg EC, Bond JP, Burns DK, Cheo DL, et al. (2000). Defective nucleotide excision repair in xpc mutant mice and its association with cancer predisposition. Mutat. Res. 459: 99-108. http://dx.doi.org/10.1016/S0921-8777(99)00068-3 
He J, Qiu LX, Wang MY, Hua RX, et al. (2012). Polymorphisms in the XPG gene and risk of gastric cancer in Chinese populations. Hum. Genet. 131: 1235-1244. http://dx.doi.org/10.1007/s00439-012-1152-8

Jiang HY, Zeng Y, Xu WD, Liu C, et al. (2015). Genetic Association between the XPG Asp1104His Polymorphism and Head and Neck Cancer Susceptibility: Evidence Based on a Meta-Analysis. Asian Pac. J. Cancer Prev. 16: 36453651. http://dx.doi.org/10.7314/APJCP.2015.16.9.3645

Kumar R, Höglund L, Zhao C, Försti A, et al. (2003). Single nucleotide polymorphisms in the XPG gene: determination of role in DNA repair and breast cancer risk. Int. J. Cancer 103: 671-675. http://dx.doi.org/10.1002/ijc.10870

Liu C, Yin Q, Hu J, Weng J, et al. (2014). Quantitative assessment of the association between XPG Asp1104His polymorphism and bladder cancer risk. Tumour Biol. 35: 1203-1209. http://dx.doi.org/10.1007/s13277-013-1161-9

Lu B, Li J, Gao Q, Yu W, et al. (2014). Laryngeal cancer risk and common single nucleotide polymorphisms in nucleotide excision repair pathway genes ERCC1, ERCC2, ERCC3, ERCC4, ERCC5 and XPA. Gene 542: 64-68. http://dx.doi. org/10.1016/j.gene.2014.02.043

Ma H, Yu H, Liu Z, Wang LE, et al. (2012). Polymorphisms of XPG/ERCC5 and risk of squamous cell carcinoma of the head and neck. Pharmacogenet. Genomics 22: 50-57. http://dx.doi.org/10.1097/FPC.0b013e32834e3cf6

Matsen CB and Neumayer LA (2013). Breast cancer: a review for the general surgeon. JAMA Surg. 148: 971-979. http:// dx.doi.org/10.1001/jamasurg.2013.3393

Mechanic LE, Millikan RC, Player J, de Cotret AR, et al. (2006). Polymorphisms in nucleotide excision repair genes, smoking and breast cancer in African Americans and whites: a population-based case-control study. Carcinogenesis 27: 1377-1385. http://dx.doi.org/10.1093/carcin/bgi330

Mirecka A, Paszkowska-Szczur K, Scott RJ, Górski B, et al. (2014). Common variants of xeroderma pigmentosum genes and prostate cancer risk. Gene 546: 156-161. http://dx.doi.org/10.1016/j.gene.2014.06.026

Mudgett JS and MacInnes MA (1990). Isolation of the functional human excision repair gene ERCC5 by intercosmid recombination. Genomics 8: 623-633. http://dx.doi.org/10.1016/0888-7543(90)90248-S

Siegel R, Ma J, Zou Z and Jemal A (2014). Cancer statistics, 2014. CA Cancer J. Clin. 64: 9-29. http://dx.doi.org/10.3322/ caac. 21208

Steck SE, Butler LM, Keku T, Antwi S, et al. (2014). Nucleotide excision repair gene polymorphisms, meat intake and colon cancer risk. Mutat. Res. 762: 24-31. http://dx.doi.org/10.1016/j.mrfmmm.2014.02.004

Takahashi E, Shiomi N and Shiomi T (1992). Precise localization of the excision repair gene, ERCC5, to human chromosome 13q32.3-q33.1 by direct R-banding fluorescence in situ hybridization. Jpn. J. Cancer Res. 83: 11171119. http://dx.doi.org/10.1111/j.1349-7006.1992.tb02731.x

Xu XM, Xie LC, Yuan LL, Hu XL, et al. (2014). Association of xeroderma pigmentosum complementation group G Asp1104His polymorphism with breast cancer risk: A cumulative meta-analysis. Mol. Clin. Oncol. 2: 1177-1181.

Yu G, Wang J, Dong J and Liu J (2015). XPC Ala499Val and XPG Asp1104His polymorphisms and digestive system cancer risk: a meta-analysis based on model-free approach. Int. J. Clin. Exp. Med. 8: 6621-6630.

Zhang C, Doherty JA, Burgess S, Hung RJ, et al.; GECCO and GAME-ON Network: CORECT, DRIVE, ELLIPSE, FOCI, and TRICL (2015). Genetic determinants of telomere length and risk of common cancers: a Mendelian randomization study. Hum. Mol. Genet. 24: 5356-5366. http://dx.doi.org/10.1093/hmg/ddv252

Zhang XJ, Liu P and Zhu F (2014). Polymorphisms of DNA repair-related genes with susceptibility and prognosis of prostate cancer. Genet. Mol. Res. 13: 4419-4424. http://dx.doi.org/10.4238/2014.January.24.20

Zhu ML, Shi TY, Hu HC, He J, et al. (2012). Polymorphisms in the ERCC5 gene and risk of esophageal squamous cell carcinoma (ESCC) in Eastern Chinese populations. PLoS One 7: e41500. http://dx.doi.org/10.1371/journal. pone. 0041500 